\title{
Francisco Varela (1946-2001): Filling the mind - brain gap: A life adventure
}

\author{
ADRIÁN G. PALACIOS ${ }^{1}$ and JUAN BACIGALUPO
}

\begin{abstract}
${ }^{1}$ Centro de Neurociencias de Valparaíso (CNV), Departamento de Fisiología, Facultad de Ciencias, Universidad de Valparaíso, Valparaíso, Chile.

${ }^{2}$ Instituto Milenio para Estudios Avanzados en Biología Celular y Biotecnología (CBB) y Departamento de Biología, Facultad de Ciencias, Universidad de Chile, Santiago, Chile.
\end{abstract}

\begin{abstract}
One of the most eminent neuroscientists recently passed away in Paris. Professor Francisco Varela was a scholar that approached science with a remarkably broad and integrative perspective, deeply contributing to a diversity of fields, from mathematics to epistemology, from immunology to neuroscience. He was strongly influenced by Buddhism and actively participated in unraveling the relationship between science and spirituality. This article introduces a special edition of Biological Research dedicated to the memory of this great man. It contains a collection of valuable contributions by various authors who collaborated with Varela at different moments of his outstanding scientific career. Their articles cover most of the fields in which he made contributions.
\end{abstract}

\begin{abstract}
"Good morning my dear friend, and in some sense I also consider you as a spiritual brother. I didn't realize what a strong feeling [it is] missing you here. I heard you were watching [by videocam] our meeting yesterday and also today, so I wanted to express my deep feeling to you as a human brother and to your contribution. In science, especially in neurology, you made great contributions, and also in our work [cf Mind and Life] on the dialogue between the science of the mind and Buddhist thought. So we'll never forget that. Until my death I will remember you."
\end{abstract}

Thus was the Dalai Lama's farewell to Francisco Varela just six days before he passed away in Paris, via a live videoconnection from a meeting held at the University of Wisconsin in Madison, USA, on the "Transformations of Mind, Brain, and Emotion: Neurobiological and BioBehavioral Research on Meditation." Evan
Thompson, one of Francisco's close collaborator's wrote "This meeting was a dream-come-true for Francisco, the best of Western brain science and Buddhist meditative practice and psychology brought together in the context of cognitive neuroscientific research. Francisco was to present his studies and findings using EEG and MEG methods at the morning session of May 22, but sadly he was unable to be there because of his illness" (Thompson, 2001).

Francisco Varela was born in Talcahuano, Chile, in 1946, the child of Raúl Varela and Corina García. Francisco and his two older brothers grew up in a prosperous intellectual and art-sensitive environment. The Varela family moved to Santiago, where the sons received a very good education. At school Francisco was a good student, with a marked interest in philosophy. After a brief incursion in the School of Medicine, Francisco obtained his undergraduate degree at the Faculty of Sciences of the University of Chile, where he received a strong foundation in biology, physics and

Correspondence: Adrián G. Palacios. Centro de Neurociencias de Valparaíso. Universidad de Valparaíso. 
mathematics. At the same time, Francisco taught himself classical and modern philosophy. After graduating he traveled to Boston to become a graduate student at Harvard University. In 3 years he received his $\mathrm{PhD}$, at the age of 24 , after doing a doctoral thesis on information processing in the insect compound eye, under the supervision of Keith Porter (Varela, 1970). This work gave rise to several publications and inspired the first of his numerous books, Los Ojos de los Insectos, (The Insect Eyes), published in Madrid in 1974. This book offers a well-informed and clear description of the anatomical, physiological and optical features of insect visual systems, and includes many original ideas about information processing in visual system. While working on his doctoral dissertation, he also became interested in cognitive phenomena and published his first independent paper on the subject, entitled "Self-consciousness: adaptation or epiphenomenona?" (Varela, 1971).

After graduating from Harvard, he returned to Chile in 1970 and assumed the position of Assistant Professor of the University of Chile, where he initiated a fruitful collaboration with the renowned neurophysiologist Humberto Maturana. Together they developed the important concept of Autopoiesis, with which they offered a definition for living beings and gave an explanation for the complex nature of them. According to their conception, a living being is a closed entity capable of generating its own components. Their provocative ideas were developed at length in their highly influential book $D e$ Máquinas y Seres Vivos (Autopoiesis and cognition: the realization of the living) (Varela and Maturana,1973), which has been translated into different languages. In this book, Maturana and Varela also made the fundamental proposition that the nervous system was a closed system. The impact of these concepts spread well beyond biological sciences to influence social sciences, philosophy and other intellectual areas. Autopoiesis became a recurrent focus in Varela's work. Indeed, within the framework imposed by an autopoietic system, he attempted to grasp the biological basis for cognitive phenomena such as subjectivity and conscious experience. By the end of his life, he and his 'Brain Dynamics Team' reached fascinating ideas based on theory and experimentation, as documented by Rudrauf et al. (2003).

The military coup of 1973 caused a massive emigration of Chilean scientists, including Varela, who settled in Boulder, Colorado, where he studied various sensory systems. At the time he also became interested in the immune system, which he envisioned as a closed network of interactions, much as he saw the nervous system. Varela developed these ideas much further in the following years, stimulated by his interactions with A. Coutinho, N. Vaz, and other prominent immunologists with whom he discussed his ideas, as is nicely described by Coutinho (2003).

During his years in Boulder he became deeply involved in Buddhist practice and philosophy, which constituted a prominent turning point of his life, since Buddhism helped him to structure his own thinking for the rest of his life. E. Rosch (2003), a close partner of Varela in his Buddhist experiences and co-author of one of his books (The Embodied Mind: Cognitive Science and Human Experience, 1991), offers a revealing personal narrative of various moments they shared over the course of many years, in which the connection between the objectivity of science and the spirituality of Buddhism and was a central issue. So deep was Varela's involvement in Buddhism that in the 1990's the Dalai Lama asked him to put together a group of scientists from diverse disciplines which, under the name of the Mind and Life Institute, met several times to discuss the link between Buddhism and Science with the Buddhist leader. Varela edited these discussions and published them in the form of two books, Gentle Bridges: Dialogs between the Cognitive Sciences and the Buddhist Tradition (Hayward and Varela, 1992), and Sleeping, Dreaming and Dying: Dialogs between the Cognitive Sciences and the Buddhist Tradition (Varela, 1997).

Varela returned to the University of Chile in 1980, where he worked for approximately 
four years. His research there dealt with the neurophysiology of human and avian color vision. His laboratory became a strong center of attraction for a number of bright students, who later followed his steps in Neuroscience with remarkable success. At that time he resumed his collaboration with Maturana, which crystallized in their well-known book El Arbol del Conocimiento (The Tree of Knowledge) (1985), also translated into multiple languages. This book provided a novel look at the biological roots of human understanding. At this time Varela became interested in such concepts as autonomy, auto-reference, auto-organization, cellular automata, artificial intelligence and experimental epistemology, all of which became part of his later intellectual adventures. Cellular automata selforganization provides a clear example where emergent properties endowed with network architecture historically and structurally coupled to the environment (Maass and Martínez, 2003).

In the mid-1980s Varela left Chile once again and established himself in Europe, where he was to reside for the rest of his life. In France he formed a research group in visual neurophysiology, which made important contributions in the field of visual perception. The visual system fascinated Varela, and his thoughts about the problem of trichromacy are reviewed in Bonnardel and Varela (2003). The authors propose that a pragmatic approach to color signals, rather than a formal reconstruction of them, allows trichromacy and color-opponency to be envisioned as an optimization of color constancy abilities in the primate spectral environment.

Varela also became involved in the study of the neuronal dynamics of the nervous system, a subject that became central to his later work. Treating the nervous system and the immune system as closed networks, he developed, in collaboration with mathematicians, theoretical formalisms to give shape to his related ideas. In addition, during those years Varela did not stop thinking about epistemological issues. He extended such studies into the early years of the next decade, closing them with a synthesis of the ideas generated from his experimental and theoretical work on comparative vision published with A. Palacios and E. Thompson in Behavioral Brain Science (Petitot, 2003). Francisco argued that perception consisted of perceptually guided action, and he coined the term 'Enaction' (or embodied cognition) to express the idea that we must see the organism and environment as bound together in reciprocal specification and selection. When enaction is discussed in the field of sensory ecology, some interesting ideas emerge, as is illustrated by Palacios and Bozinovic (2003).

In the mid-1990s Varela experienced his next and final crucial turning point, as he started experimental work on human consciousness, something that years earlier had been considered virtually inaccessible experimentally. He arrived to this issue through the study of the synchrony of the electrical brain wave activity (Le van Quyen, 2003) and its underlying anatomical foundations (Aboitiz et al, 2003). Le van Quyen's contribution presents a clear description of Varela's conceptions about the integrative dynamic synchronous neuronal activity that takes place in various areas of the brain, which he thought to underlie high-level functions. Varela's research quickly incorporated new and powerful non-invasive technology that allows for monitoring wakeful human brain activity in order to study complex behaviors. One major outcome from such studies, which included a sophisticated mathematical analysis of brain wave activity, was a novel procedure for anticipating seizures in epileptic patients, a truly remarkable achievement. However, large brains, such as in humans, present a challenging problem to explaining wave synchrony: how is it possible to synchronize the activity of neurons located in different hemispheres, at distances that appear to be incompatible with the frequencies of the synchronized waves? Aboitizet al. (2003) discuss this fundamental issue in their article and report the presence of inter-hemispheric fast conductive fibers that allow efficient intercommunication among distant neuronal groups.

Despite the fact that most of Varela's scientific career took place outside of Chile, 
he always kept close contact with Chilean scientists working in diverse areas of research, from biology to mathematics. For example, in 1999 Francisco joined a commission named by the Chilean Government in relation to the Millennium Initiative, an important joint venture with the World Bank to support scientific research. At the time, Francisco had already have a liver transplant. Just six months before his death he gave the Millennium Conference 2000, sponsored by the Millennium Institute CBB, which was his last public presentation in Chile. In his conference, "Brain and Consciousness," he enthralled the enthusiastic standing-roomonly audience with his most recent adventures in the field of the human mind. He also took the time to visit the Center for Neuroscience in Valparaíso, with which he had close contact, and to release his last book, "El Fenómeno de la Vida" (The Phenomenon of Life) (2002).

We invite the reader to read through the articles presented in this issue considering the course of Francisco Varela's life and career, in which social, scientific, academic and spiritual experiences intertwined in an enacting dance.

\section{ACKNOWLEDGEMENTS}

We are profoundly indebted to Francisco for the invaluable influence that he radiated over us and for his charming way of he used to ask 'Why not?' We also wish to thank Amy Cohen-Varela for her transcription of the video-taped session with the Dalai Lama (2002).

This work was supported by Mideplan ICM grant \# P99-037-F (AGP) and P99031-F (JB).

\section{REFERENCES}

ABOITIZ F, LÓPEZ J, MONTIEL J (2003) Long distance communication in the human brain-timing constraints for interhemispheric synchrony and the origin of brain lateralization. Biol res 36 , this issue
BACIGALUPO J, PALACIOS AG (2001): Francisco Varela, Faro del Pensamiento http://www.ciencia.cl/ CienciaAlDia/volumen 4/numero2/homenaje/ homenaje.html. Ciencia al Dia Internacional. 2001, 2 ( vol 4)

BONNARDEL V, VARELA F (2003) Color vision in the comb frequency domain. Biol Res 36, this issue

COUTINHO A (2003) A walk with Francisco Varela from first- to second-generation networks: in search of the structure, dynamics and metadynamics of an organismcentered immune system. Biol Res 36 , this issue

HAYWARD J, VARELA F (Eds.) (1992) Gentle Bridges: Dialogues between the Cognitive Sciences and the Buddhist Tradition. Boston: Shambhala Publishers

JIMÉNEZ G (2001) Francisco Varela: Un Argonauta del Conocer http://www.elmostrador.cl/modulos/

LE VAN QUYEN M (2003) Disentangling the dynamic core: a research program for a neurodynamics al the large scale. Biol Res 36, this issue

LETELIER JC (2001) The scientific paths of Francisco Varela (1946-2001). Biol Res 34 (2): vii-xiii

MAASS A MARTÍNEZ, S (2003) Evolution of probability measures by cellular automata on algebraic topological Markov chains. Biol Res 36, this issue

MATURANA HR, VARELA F (1985) El árbol del conocimiento. Santiago de Chile: Editorial Universitaria

PALACIOS AG, BOZINOVIC F (2003) An "Enactive" approach to physiological and behavioral ecology: thoughts on a table. Biol Res 36 , this issue

PETITOT J (2003) Morphodynamical enaction: the case of color. Biol Res 36, this issue

ROSCH E (2003) For Francisco Varela: explorer of the phenomenal world. Biol Res 36, this issue

ROY JE (2001) Francisco J. Varela (September 7, 1946May 28, 2001). Consciousness and Cognition 10: 594-597

RUDRAUF D, LUTZ A, COSMELLI D, LACHAUX JP, LE VAN QUYEN M (2003) From autopoiesis to neurophenomenology: Francisco Varela's exploration of the biophysics of being. Biol Res 36, this issue

THOMPSON E (2001) Obituary: http:// psyche.cs.monash.edu.au/v7/psyche-7-12thompson.html

VARELA F (1970) Insect retinas: information processing in the compound eye. PhD Dissertation, Harvard University, USA

VARELA F (1971) Self-consciousness: adaptation or epiphenomenona? (Studium Generale 24: 426439

VARELA F (1974) Los Ojos de los Insectos, Madrid: Editorial Alhambra

VARELA F, MATURANA HR (1973) De Máquinas y Seres Vivos: Una teoría sobre la organización biológica, Santiago de Chile: Editorial Universitaria

VARELA F, THOMPSON E, ROSCH E (1991) The Embodied Mind: Cognitive science and human experience. Cambridge, MA: MIT Press

VARELA F (1997) Sleeping, Dreaming and Dying: Dialogues between the Sciences and the Buddhist Tradition, Boston: Wisdom Books

VARELA F (2002) El fenómeno de la vida. Santiago de Chile: Dolmen Ediciones.

VARELA F: Web Page: http://web.ccr.jussieu.fr/varela 